\title{
Professor Edson Saad
}

\author{
Charles Mady \\ Evandro Tinoco Mesquita \\ Whady A. Hueb
}

Morreu o Prof. Dr. Edson Abdalla Saad. Paulista de Igarapava, filho de imigrantes libaneses, quis a providência que essa semente dos cedros da terra natal de seus ancestrais aqui germinasse. Essa herança moral e cultural forjou sua personalidade e caráter, amalgamando-a com os ingredientes da terra nova adotada. Dessa saudável mistura, dessa eugenia ambiental positiva, surgiu um carioca por adoção, composto por ingredientes como bondade, sabedoria e tolerância.

Formou-se em medicina no Rio de Janeiro e abraçou a cardiologia com entusiasmo e determinação. Ainda muito jovem, tornou-se Professor Titular de duas universidades federais, a Federal Fluminense (UFF) e Federal do Rio de Janeiro (UFRJ). Nesta, participou da criação da pósgraduação em nível de mestrado e doutorado. Colaborou na formação de centenas de cardiologistas, que hoje atuam e ensinam em todo o país. Sua obra Semiologia Cardiovascular, publicada em 2003, é uma de suas grandes realizações, servindo como marco cultural médico para as atuais e próximas gerações. 0 professor Saad era membro da Academia Nacional de Medicina e recentemente recebeu o importante título de Professor Emérito da UFRJ.

Lançou as sementes para a criação do Instituto de Doenças do Tórax da UFRJ, tendo feito inúmeros contatos com o Instituto do Coração do Hospital das Clínicas da Faculdade de Medicina da USP com o objetivo de formar parcerias para criação, gestão e logística institucional que viabilizasse a implementação desse marco histórico. Aliás, suas ligações com o InCor eram antigas e fraternais. Quando necessitou de cirurgia de revascularização miocárdica, no InCor foi operado, ficando sob os cuidados de um de nós (Whady A. Hueb), juntamente com seus amigos Prof. Dr. Giovanni Bellotti, que também não está mais entre nós, e Prof. Dr. Fulvio Pileggi, Professor Titular na ocasião. Esse vínculo foi mantido na atual administração, gerida pelo Prof. Dr. José A. F. Ramires, traduzindo-se em participação ativa e homenagens dos cursos de Pós-Graduação UFF-InCor.

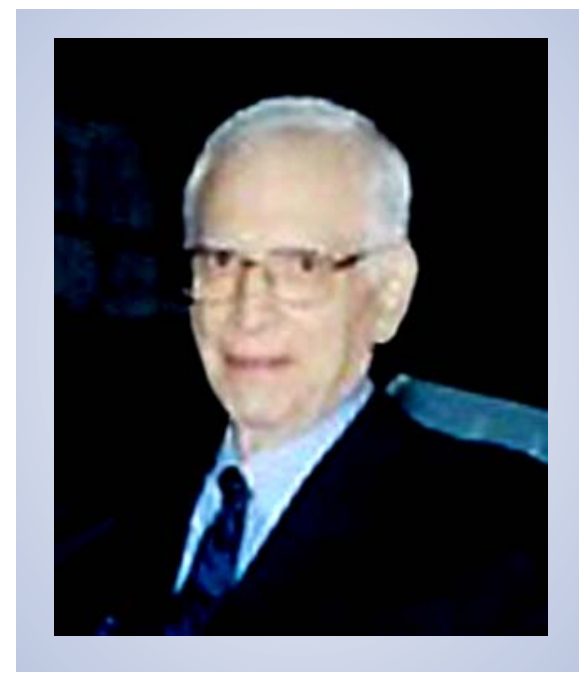

Como dizia Spinoza, "a certeza é saber que se sabe". Essa postura gera uma ponta de humildade típica daqueles cujas mentes deram largos passos em direção à sabedoria. O professor Saad sabia ouvir com tranqüilidade e argumentar com senso crítico construtivo. Respeitava aquilo que dizia Menocal em seu livro O Ornamento do Mundo, que "as contradições são positivas e produtivas", ao descrever a tolerância civilizada, adulta entre cristãos, judeus e mulçumanos na época moura da Península Ibérica. Sabia também que a profissão, por si só, não nos aproxima do equilíbrio. Soube cercar-se da família e dos amigos. Sua esposa, Mônica, foi sua maior conselheira.

Parte um homem da época romântica da medicina. Lembramo-nos muito bem daquela alegria juvenil por ele demonstrada após a entrevista realizada com o Prof. Dr. Luiz Décourt, outro remanescente dessa época romântica e gigante do humanismo ligado à medicina.

Caro Edson, este não é um adeus. É um até logo. Aguarde-nos para continuarmos as nossas conversas. 